\title{
French research threatened
}

\section{Dumont d'Urville \& Paris}

THE Expéditions Polaires Françaises (EPF), the organization responsible for running French research in the Antarctic, may have to cancel its entire 1991-92 programme, if two government ministries do not resolve a clash over funding. Ironically, the crisis comes at a time when French polar research was due to expand and could set back plans to create a new permanent base on the Antarctic continent intended to be an international centre for research on the ozone layer and in glaciology

At the heart of the imbroglio is a complex system of funding Antarctic research that mixes French claims to sovereignty with research activities.

EPF finances its Antarctic programme mostly with grants from Terres Australes et Antarctiques Françaises (TAAF), a government body set up in 1955 to preserve French territorial claims to Terre Adélie (part of the Antarctic continent) and four islands near the Antarctic circle. Under the terms of the 1961 Antarctic Treaty, while claims to sovereignty are suspended by the seven signatory nations, one means to keep a foot in the Antarctic door is to maintain a permanent research base. Thus by supporting research, TAAF kills two birds with one stone.

TAAF's dual responsibility means it is funded partly out of the national civil research budget, and partly from money set aside by the ministry for overseas departments and territories (DOM-TOM) to safeguard territorial interests. But while the research minister, Hubert $\mathrm{Cu}$ rien, has maintained TAAF's civil research grant at about FF45 million (\$9 million), the DOM-TOM has axed its grant progressively from FF103 million in 1980 to FF75 million last year, when inflation is taken into account. As a result, EPF saw its own budget for Antarctic research fall from FF26 million in 1989 to FF25.5 million last year, with inflation running at about 4 per cent. At the end of 1990 a budget proposal of FF26 million for EPF was thrown out by the DOM-TOM and a new budget of FF20 million is now being considered.

According to Bernard Morlet, secretary general of EPF, a "minimal programme" for Terre Adélie could go ahead with an EPF grant of FF26 million. This would allow about 30 staff and technicians to man the Dumont d'Urville base during the Antarctic winter (March to November) and to support a "reduced" summer campaign. Morlet estimates that a "full research programme" would cost FF27.7 million. That such relatively small sums can make the difference between a full programme and no campaign at all is due to high fixed costs, around FF17.5 million, simply for transport and the running of the base. Less than FF2 million is spent on research itself.

"It's a dramatic situation", says Morlet. In November last year, fuel costs for the supply ship rose from FF800,000 to FF2 million as a result of the Gulf crisis. The 1990 research programme was possible, he says, only because both the TAAF and EPF found money from other sources, now exhausted. Unless the shortfall of FF6-8 million is made up, the 1991-92 programme will have to be scrapped. "It now looks as though we will have to close the base in Terre Adélie next year", he says.

One official at EPF attributes the funding problems partly to the fact that the DOM-TOM is uninterested in research and has little interest in the TAAF districts. It is a "political ministry", he says, and "there are no votes in the territories and no economic or strategic interests". At the MRT, Françise Praderie, head of the Earth, ocean, space and environment department, confirmed that the outlook is gloomy and admitted that the 1991-92 Antarctic programme could be cancelled.

But what is causing most concern at MRT is the apparent volte-face of the DOM-TOM ministry over plans to expand French polar research. In February last year, the minister for DOM-TOM, Louis le Pensec and research minister, Hubert Curien announced plans to create a new polar research institute, to open a new permanent research base at DOME C, 1,000 kilometres inland on the Antarctic continent, and to renew French research interest in the Arctic. As a result of the DOM-TOM cutbacks, the TAAF now has a budget deficit and is unable to make a commitment to the creation of a new institute.

Meanwhile, work on a controversial FF100 million landing strip being built at Dumont d'Urville would have to stop if the 1991-92 campaign is cancelled.

The airstrip is an essential component in plans for a base at DOME C, scheduled to be a key element in the new international Network for the Detection of Stratospheric Changes, monitoring variations in the ozone layer from different observation centres. Although Gérard Mégic, president of the international ozone commission, remains phlegmatic about DOME $\mathrm{C}$, he is concerned about the interruption to ongoing observations if the Dumont d'Urville base is closed. "DOME $\mathrm{C}$ is like a space project, it may take 15 years to achieve. If there are budgetary changes, it will be a problem, but this is one of the difficulties." "But", he adds, "we need continuity to observe the evolution of the atmosphere. Stopping the programme would be very bad, because the phenomena are fragile." Peter Coles
French leave the circumflex unscathed

\section{London}

THE eighth month of the year remains août, complete with circumflex now that the august Académie Française has effectively shelved a series of rationalizations announced last year. The changes would have removed most circumflexes, in deference to the needs of wordprocessors, and made other spelling and hyphenation 'rectifications' (Nature 347, 323; 1990).

The uproar that greeted the original announcement united Frenchmen as diverse as Eugene Ionescu and Jean-Michel Jarre, and the Académie has now voted not to publish the list of changes in its official bulletin. This means that schools will not teach the adjusted spellings, and lexicographers will not document them. All 29 of the academicians voting were against promulgating the changes, which had previously been approved unanimously but, it seems, without thorough examination.

Charles Wenz

\section{CLIMATE DATA}

\section{Too much of a good thing}

\section{Washington}

Climate data from US satellites and weather stations is accumulating at a rate of more than 1,000 magnetic tapes a day, a flow that will double the size of the current archives in a year, and increase them 100fold by the end of the decade. But funding for their maintenance and storage has dropped, from $\$ 27$ million in 1983 to $\$ 21$ million in 1989 , leaving nearly half the current collection in poor condition and some irreplaceable data already lost, according to a recent report by the General Accounting Office (GAO), Congress's investigative arm.

Although the National Oceanic and Atmospheric Administration (NOAA), the US agency assigned to follow climate patterns, has proposed a data-management initiative called NOAANET, the plan was cancelled during the 1980 s by its parent agency, the Department of Commerce, $\mathrm{GAO}$ reports. Commerce argued that such functions should be transferred to the private sector, in line with the Reagan administration's emphasis on privatization. Anticipating that such a transfer would save millions, Commerce cut the NOAA data-management budget accordingly. By the time the agency realized that the private sector had little interest in managing NOAA's data, NOAANET had been killed and thousands of tapes were rotting in damp basements. Unless the NOAA data-management budget is vastly increased over the next several years, it risks drowning in a flood of new satellite observations, GAO warns.

Christopher Anderson 